\title{
Tinjauan Ekonomi Islam atas Sistem Pengupahan Karyawan Home Industry Meubel
}

\author{
Ade Kurnia'; Abdul Wahab² Urbanus Uma Leu3 \\ UIN Alauddin Makassar \\ Jln,. HM Yasin Limpo No.36, Samata-Gowa \\ E-mail : kurnia_ade198@gmail.com; abdulwahabo91@gmail.com; \\ urbanus_uma@gmail.com
}

Diterima: 2 Juni 2018; Direvisi: 28 Juni 2018; Diterbitkan: 5 Juli 2018

\begin{abstract}
Abstrak,
Penelitian ini bertujuan untuk melihat sistem pengupahan yang diterapkan pada karyawan di home industry meubel dari sudut pandang ekonomi Islam. Untuk mengungkap fenomena tersebut, maka penelitian ini didesain sebagai penelitian kualitatif dengan metode deskriptif. Jumlah sampel informan yang digunakan adalah 6 orang, dengan teknik pengambilan data melalui dokumentasi, wawancara, dan studi pustaka. Hasil penelitan menunjukkan bahwa sistem pegupahan karyawan pada home industry meubel ini menggunakan sistem upah borongan, yang dimana sistem ini pekerja dituntut melakukan pekerjaanya sesuai waktu yang telah disepakati dan setelah barang jadi kemudian upahnya dibayarkan. Dalam perspektif ekonomi Islam, sistem yang digunakan secara tidak langsung telah menerapkan sistem ekonomi Islam.
\end{abstract}

Kata Kunci: Industri Meubel, Upah, Ekonomi Islam

\section{Abstract,}

This study aims to look at the wage system applied to employees in the home industry furniture from an Islamic economic point of view. To reveal the phenomenon, then this research is designed as qualitative research with descriptive method. The number of sample informants used is 6 people, with data collection techniques through documentation, interviews, and literature study. The result of the research indicates that employee's employment system in the furniture industry uses a wholesale wage system, in which the worker system is required to do the work according to the agreed time and after the finished goods and then the wages are paid. In the perspective of Islamic economics, the system used indirectly has applied the Islamic economic system.

Keywords: Furniture Indstry, Wage, Islamic Economics

\section{PENDAHULUAN}

Upah di dalam teori ekonomi secara umum dimaknai sebagai harga yang dibayarkan kepada pekerja atas jasanya dalam produksi kekayaan seperti faktor produksi lainnya, tenaga kerja diberikan imbalan atas jasanya yang disebut upah⒈ Dalam konteks pengupahan

1 Azalur Rahman, Doktrin Ekonomi Islam Jilid 2, terjemahan Soeroyo dan Nastagin, (Jogjarkarta: Dana Bhakti Wakaf, 1995), hal.361. 
karyawan, dijelaskan bahwa Pengupahan buruh merupakan bentuk pemberian kompensasi yang diberikan oleh majikan kepada buruh. Kompensasi tersebut bersifat financial dan merupakan yang utama dari bentuk kompensasi yang ada bagi buruh Karena gaji yang diterima buruh berfungsi sebagai penunjang untuk kelangsungan hidupnya, yaitu untuk memenuhi sandang, pangan, papan, pendidikan²

Buruh yang bekerja akan mendapatkan upah berdasarkan berapa hasil yang dihasilkan. Namun, dalam proses produksi pekerja melakukan pekerjaannya dari proses awal sampai akhir tanpa adanya pembagian pekerjaan secara pasti. Dari hal tersebut muncul beberapa hal yang positif dan negatif yang muncul terhadap sistem pengupahan tersebut. Karena itu perlu di perhatikan standar upah agar tidak memberikan kerugian kepada kedua belah pihak yaitu pihak perusahaan dan buruh, seperti yang terjadi pada masa Rasulullah saw dan pada masa kekhalifahan.

Industri meubel rumahan yang berada di Kelurahan Antang, Kota Makassar menggunakan karyawan yang bekerja dengan sistem borongan. Artinya, para pekerja melakukan pekerjaannya dengan menyelesaikan pesanan meubel dari konsumen dan akan diupah setiap pesanan selesai dengan besaran sesuai dengan perjanjian diawal. Dengan kata lain, para pekerja meubel harus menyelesaikan secara cepat pesanan meubel. Kemudian dalam hal ini para buruh yang di upah secara borongan tidak diketahui secara pasti berapa yang akan didapatkan dan sistem pembagian kerja yang tidak jelas. Agama Islam memberikan pedoman bagi kehidupan manusia dalam bidang perekonomian tidak memberikan landasan yang bersifat praktis, berapa besarnya upah yang harus diberikan kepada buruh untuk mencukupi kebutuhan hidup.

Berdasarkan pada hal tersebut, maka penelitian ini dilakukan untuk melihat sistem pengupahan yang berlaku bagi karyawan industri meubel rumahan dari sisi ekonomi Islam.

\section{TINJAUAN TEORITIK}

\section{Pengertian Upah}

Kompensasi adalah imbalan jasa yang diberikan secara teratur dan dalam jumlah tertentu oleh perusahaan kepada para karyawan atas kontribusi tenaganya yang telah diberikannya untuk mencapai tujuan perusahaan. Kompensasi ini dapat berupa upah dan gaji. Sebenarnya pengertian antara upah dan gaji adalah sinonim, tetapi upah lebih banyak dipakai untuk para pekerja (buruh), sedangkan gaji, biasanya merupakan kompensasi

${ }^{2}$ Sadono Sukirno, Mikro Ekonomi Pengantar Teori, Edisi III, (Jakarta: PT. Raja Grafindo Persada: 2005), hal. 350. 
untuk para pegawai. Gaji biasanya diberikan bulanan, dalam jumlah pasti, sedangkan upah dapat bulanan atau kurang dari itu dan sangat dipengaruhi oleh volume output yang dihasilkan oleh setiap individu³.

Dalam definisi yang lain, dijelaskan bahwa upah merupakan hak pekerja yang diterima dan dinyatakan dalam bentuk uang sebagai imbalan dari pengusaha atau pemberi kerja kepada pekerja yang ditetapkan dan dibayarkan menurut suatu perjanjian kerja, kesepakatan, atau peraturan perundang-undangan, termasuk tunjangan bagi pekerja dan keluarganya atas suatu pekerjaan yang telah atau akan dilakukan4.

Adapun menurut Badan Pusat Statistik, yang dimaksud dengan upah adalah Penerimaan karyawan baik berupa uang ataupun barang selama sebulan yang dibayarkan oleh perusahaan setelah dikurangi dengan potongan-potongan, iuran wajib, pajak penghasilan dan dan sebagainya5.

Upah dalam bahasa Arab sering disebut dengan ajrun/ajrān yang berarti memberi upah kata ajrān mengandung dua arti, yaitu balasan atas pekerjaan dan pahala. Sedangkan upah menurut istilah adalah uang dan sebagainya yang dibayarkan sebagai balas jasa atau bayaran atas tenaga yang telah dicurahkan untuk mengerjakan sesuatu. Upah diberikan sebagai balas jasa atau penggantian kerugian yang diterima oleh pihak buruh karena atas pencurahan tenaga kerjanya kepada orang lain yang berstatus sebagai majikan.

Ijarah berasal dari kata al-ajru, berarti al iwadh (upah atau ganti). Wahbah alZuuhaily menjelaskan ijarah menurut bahasa, yaitu bai' al-manfaah yang berarti jual beli manfaat. Sementara itu pengertian ijarah menurut istilah adalah Akad yang lazim atas suatu manfaat pada waktu tertentu dengan harga tertentu.

\section{Sistem Pengupahan}

Menurut cara menetapkan upah, terdapat berbagai sistem pengupahan menurut ilmu ekonomi.

\section{$\underline{\text { Sistem Upah Menurut Waktu }}$}

Besarnya sistem upah ini ditentukan berdasarkan waktu kerja karyawan yaitu upah yang diberikan per jam, upah yang diberikan per hari, upah yang diberikan per minggu dan upah yang diberikan per bulan. Dalam sistem upah menurut waktu, pembayaran upah dapat dilakukan dengan mudah selain itu, perhitungan upah ini juga tidak menyulitkan. Namun

3 Basu Swastha DH., SE., MBA \& Ibnu Sukotjo W. SE., Pengantar Bisnis Modern Pengatar Ekonomi Perusahaan Modern,(Yogyakarta: Liberty : 2007), h. 267.

4 UU Nomor 13 Tahun 2003 Tentang Ketenagakerjaan Pasal 1 Ayat 30.

5 Badan Pusat Statistika, Indikator Ketenagakerjaan Mei 2004, (Jakarta: BPS, 2004), Hal.2 
sayangnya sistem upah menurut waktu ini bila dilaksanakan secara murni maka tidak akan ada perbedaan antara karyawan yang rajin dengan karyawan yang tidak rajin, sehingga karyawan tidak memiliki dorongan untuk bekerja lebih baik lagi.

\section{Sistem Upah Menurut Kesatuan Hasil}

Dalam sistem upah menurut kesatuan hasil ini pada umumnya digunakan pada perusahaan industri. Untuk jumlah upah yang akan diterima oleh karyawan bergantung pada jumlah produksi atau hasil yang dicapai oleh masing-masing karyawan. Olah karena itu, karyawan yang semakin rajin untuk mencapai upah yang lebih tinggi. Namun bila tidak dilakukan kontrol mutu yang ketat maka akan menghasilkan mutu barang yang rendah. Guna mengatasi kondisi tersebut maka langkah yang dapat dilakukan yaitu pengendalian mutu secara cermat dan ditetapkan batasan dalam upah minimal, tanpa memperhatikan hasil kerjanya. Selain jumlah hasil perlu pula memasukkan persyaratan mutu untuk metapkan besarnya upah.

\section{Sistem Upah Borongan}

Dalam sistem upah borongan muncul disebabkan karena perusahaan tidak perlu menanggung resiko yang berkaitan dengan karyawan. Perusahaan juga tidak perlu menyeleksi dan mencari pekerja yang dibutuhkan. Untuk mengtasi hal tersebut, pada umumnya upah sistem borongan lebih mahal dibandingkan upah harian.Untuk besarnya upah yang diterima dalam sistem borongan ini ditentukan oleh jumlah barang yang dihasilkan oleh seorang karyawan atau sekelompok karyawan. Guna menjaga mutu hasil pekerjaan, ketentuan dari barang yang dihasilkan perlu ditentukan terlebih dahulu dan disepakati bersama termasuk kondisi dan persyaratan kerja, perlengkapan yang digunakan dan cara bekerja.

\section{Penentuan Upah}

Menyangkut penentuan upah kerja, syari'at Islam tidak memberikan ketentuan rinci secara tekstual baik dalam ketentuan al-Qur'an maupun Sunnah Rasul. Secara umum, ketentuan al- Qur'an yang ada kaitannya dengan penentuan upah kerja adalah QS. An-Nahl ayat 90 .

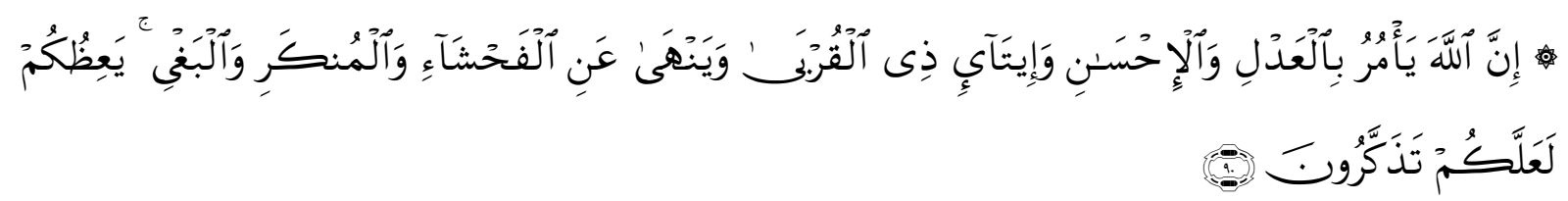


Terjemahnya:

Sesungguhnya Allah menyuruh (kamu) Berlaku adil dan berbuat kebajikan, memberi kepada kaum kerabat, dan Allah melarang dari perbuatan keji, kemungkaran dan permusuhan. Dia memberi pengajaran kepadamu agar kamu dapat mengambil pelajaran.

Apabila ayat tersebut dikaitkan dengan perjanjian kerja, maka dapat dipahami bahwa Allah swt memerintahkan kepada para pemberi pekerjaan untuk berlaku adil, berbuat baik, dan dermawan kepada para pekerjaannya. Kata "kerabat" dalam ayat tersebut dapat diartikan "tenaga kerja", sebab para pekerja tersebut sudah merupakan bagian dari perusahaan, dan jika bukan dari jerih payah pekerja tidak mungkin usaha majikan dapat berhasil. Selain itu, dari ayat tersebut dapat ditarik pengertian bahwa pemberi kerja dilarang Allah untuk berbuat keji dan melakukan penindasan (seperti menganiaya).

Landasan hukum Islam lainnya yang dapat dijadikan sebagai rujukan dalam penentuan upah adalah hadis Rasulullah saw, yang artinya :

Dari Abi Said al Khudri ra. sesungguhnya Nabi SAW bersabda: "Barang siapa mempekerjakan seorang pekerja, maka harus disebutkan upahnya” (H.R. Abdur Razak sanadnya terputus, dan al Baihaqi menyambungkan sanadnya dari arah Abi Hanifah) kitab Bulughul Maram dan Ibanatul Ahkam.

Hadits tersebut Rasulullah telah memberikan petunjuk, supaya majikan terlebih dahulu memberikan informasi tentang besarnya upah yang akan diterima oleh pekerja sebelum ia mulai melakukan pekerjaannya. Dengan adanya informasi besaran upah yang diterima, diharapkan dapat memberikan dorongan semangat untuk bekerja serta memberikan kenyamanan dalam pekerjaan. Mereka akan menjalankan pekerjaan sesuai dengan kesepakatan kontrak kerja dengan majikan.

Membayar upah sebelum keringatnya kering Rasulullah SAW menganjurkan majikan untuk membayarkan upah para pekerja setelah mereka selesai melakukan pekerjaannya. Ketentuan tersebut untuk menghilangkan keraguan pekerja atau kekhawatirannya bahwa upah mereka akan dibayarkan, atau akan mengalami keterlambatan tanpa adanya alasan yang dibenarkan.

\section{METODE PENELITIAN}

\section{Jenis Penelitian}

Jenis metode penelitian yang peneliti pakai adalah jenis metode penelitian kualitatif. Penelitian kualitatif adalah riset yang bersifat dekskriptif dan cenderung menggunakan analisis dengan pendekatan induktif. Proses dan makna (prespektif subyek) lebih ditonjolkan 
dalam penelitian kualitatif. Landasan teori dimanfaatkan sebagai pemandu agar fokus penelitian sesuai dengan fakta di lapangan ${ }^{6}$

\section{Pendekatan Penelitian}

Pendekatan penelitian yang digunakan dalam penelitian ini terdiri atas 3 pendekatan. Pertama, pendekatan sosiologi yaitu pendekatan yang dilakukan peneliti melalui interaksi lingkungan sesuai dengan unit sosial, individu, kelompok, lembaga, atau masyarakat. Kedua, pendekatan ekonomi yaitu pendekatan yang dilakukan peneliti melalui kegiatan transaksi yang dilakukan individu, unit sosial, kelompok, lembaga atau pun masyarakat yang berpengaruh terhadap peningkatan taraf hidup masyarkat tersebut. Ketiga, pendekatan normatif yaitu pendekatan yang dilakukan berdasarkan teks-teks al-Qur'an dan al-Hadits yang menyngkut tentang isi penelitian.

\section{Pengumpulan Data}

Data yang dibutuhkan dalam penelitian kualitatif umumnya berupa data primer yang diperoleh dari informan. Demikian pula penelitian ini, juga menggunakan data primer yang diperoleh dari informan, yaitu para pekerja dan pemilik industri mebel rumahan. Adapun teknik pengumpulan datanya dilakukan melalui wawancara, dokumentasi, dan studi pustaka.

Teknik wawancara merupakan sebuah proses memperoleh keterangan untuk tujuan penelitian dengan cara tanya jawab, sambil bertatap muka antara pewawancara dengan informan menggunakan alat yang dinamakan interview guide (panduan wawancara).

Dokumentasi berasal dari kata dokumen yang artinya barang-barang yang tertulis. Dalam melaksanakan metode dokumentasi, peneliti menyelidiki benda- benda tertulis seperti buku-buku, majalah, dokumen, catatan harian, dan sebagainya. Hasil penelitian dari observasi dan wawancara, akan lebih kridibel/dapat dipercaya bila didukung dengan dokumentasi.

Studi pustaka adalah teknik pengumpulan data dengan menggunakan buku atau referensi sebagai penunjang penelitian, dan dengan melengkapi atau mencari data-data yang diperlukan peneliti dari literature, referensi, majalah, makalah, dan yang lainnya.

\section{Pengolahan Data}

Analisis data dalam sebuah penelitian sangat dibutuhkan bahkan merupakan bagian yang sangat menentukan dari beberapa langka penelitian sebelumnya. Dalam penelitian kualitatif, analisis data harus seiring dengan pengumpulan fakta-fakta dilapangan, dengan

\footnotetext{
${ }^{6}$ Burhan Bungin, Penelitian Kualitatif, (Jakarta: Kencana, 2009), hal. 4.
} 
demikian analisis data dapat dilakukan sepanjang proses penelitian dengan menggunakan teknik analisa.

Adapun Pengabsahan data dilakukan dengan prosedur yaitu meliputi uji credibility (validitas internal) dan transferability (validitas eksternal). Uji validitas intenal adalah data atau kepercayaan terhadap data hasil penelitian kualitatif dapat dilakukan antara lain dengan cara perpanjangan pengamatan, peningkatan ketekunan dalam penelitian, triangulasi, diskusi dengan teman teman sejawat, analisis kasus negatif dan memberi chek. Namun karena penelitian ini menggunakan berbagai sumber data dan informasi yang akurat, maka cara yang tepat digunakan adalah dengan menggunakan metode triangulasi.

Norman K. Denkin mendefinisikan triangulasi sebagai gabungan atau kombinasi berbagai metode yang dipakai mengkaji fenomena yang saling terkait dari sudut pandang dan perspektif yang berbeda. Menurutnya, triangulasi meliputi 4 hal yaitu triangulasi metode, triangulasi antara peneliti, triangulasi sumber dan triangulasi teori.46 Namun peneliti hanya menggunakan 2 dari 4 jenis triangulasi untuk menyelaraskan penelitian ini, yaitu:

- Triangulasi sumber data, yaitu menggali kebenaran informasi tentu melalui berbagai metode dan sumber perolehan data. Misalnya, selain melalui wawancara dan observasi, peneliti bisa menggunakan observasi terlibat (participant obervation), dokumen tertulis, arsif, dokumen sejarah, catatan resmi, catatan atau tulisan pribadi dan gambar atau foto. Tentu masing-masing cara itu akan menghasilkan bukti atau data yang berbeda, yang selanjutnya akan memberikan pandangan (insights) yang berbeda pula mengenai fenomena yang diteliti. Berbagai pandangan itu akan melahirkan keluasan pengetahuan untuk memperoleh kebenaran handal.

- Triangulasi teori, yaitu hasil akhir penelitian kualitatif berupa sebuah rumusan informasi atau thesis statement. Informasi tersebut selanjutnya dibandingkan dengan perspektif teori yang televan untuk menghindari bias individual peneliti atas temuan atau kesimpulan yang dihasilkan. Selain itu, t riangulasi teori dapat meningkatkan kedalaman pemahaman asalkan peneliti mampu menggali pengetahuan teoretik secara mendalam atas hasil analisis data yang telah diperoleh.

Validitas eksternal menunjukkan derajat ketetapan atau dapat diterapkannya hasil penelitian ke objek penelitian lain. Nilai transfer berkenaan dengan pernyataan, hingga hasil penelitian dapat diterapkan atau digunakan. Uji ini dilakukan dengan mebuat hasil penelitian atau laporan atas penelitian dengan uraian rinci, jelas, sistematis dan dapat dipercaya.47 Dengan demikian pembaca jadi jelas atas hasil penelitian, sehingga dapat menentukan dapat atau tidaknya mengaplikasikan hasil penelitian tersebut di tempat lain. 


\section{HASIL DAN PEMBAHASAN}

\section{Sistem Pengupahan yang Berjalan pada Industri Mebel Rumahan di Antang}

Mekanisme pengupahan karyawan pada Home Industry Meubel di Kelurahan Antang Kecamtan Manggala ini pada umumnya menggunakan sistem upah borongan atau upah menurut hasil karena pemberian upah diberikan setelah pesanan meubel selesai. Dimana para pekerja mendapatkan upah sesuai dengan bahan baku yang diinginka kosumen untuk di produksi seperti kayu atau papan HPL.

Adapun proses yang di lalui sebelum para karyawan di home industry meubel di Kelurahan Antang Kecamtan Manggala ini mulai dari konsumen datang memesan pesanan meubelnya hinggah para pekerja menerima upah dari hasil pesanan konsumen. Pertamatama para pemilik usaha menerima pesanan dari konsumen yang meliputi : model, ukuran, bahan yang ingin di gunnakan, warna, dan waktu. Selanjutnya pemiliki usaha mencatat pesanan konsumen kemudian menggambar modelnya beserta mengghitung biaya produksi. Pada umumnya bisnis merupakan kegiatan atau usaha yang dilakukan untuk memperoleh keuntungan sesuai dengan tujuan dan target yang diinginkan.51 Maka setelah pemilik usaha menghitung modal yaitu meliputi bahan yang digunakan, ongkos pekerja, dan keuntungan maka didapatlah berapa ongkos yang diberikan kepada konsumen.

Selanjutnya para pekerja ini melakukan pekerjaanya sesuai dengan perjanjian di awal seperti : bahan apa yang di pakai, model meubel seperti apa, ukurannya berapa, warna apa dan berapa lama dikerjakan (target waktu). Sebelum para karyawan menerima upahnya para karyawan tersebut harus menyelesaikan pesanan konsumen.

Setelah memberitahukan konsumen tentang lama pembuatan meubel dengan tenggang waktu yang agak lebih lama, para pemilik usaha ini beralasan bahwa hal ini dilakukan agar menghindari kelambatan pembuatan meubel yang biasanya disebabkan karena para pekerja yang lambat atau masalah teknis di luar perkiraan.

Karyawan meubel di Home Industry Meubel di Kelurahan Antang Kecamtan Manggala ini mengerjakan pesanan sesuai dengan ukuran dan modelnya, untuk lemari 3-5 hari, kitchen set 1 minggu, meja kantor 4-5 hari, lama pengerjaan meubel tersebut diluar dari masalah non teknis seperti karaywan lambat atau sakit.

Setelah pengerjaan meubel memasuki tahap finishing, pemilik meubel menghubungi konsumenya dan selanjutanya dilakukan pengantaran ke lokasi konsumen. Untuk pengantaran para pemilik usaha meubel tidak memberikan ongkos pengantaran, tetapi ada ongkos pemasangan jika meubel itu memang sifatnya harus di pasang.

Upah karyawan meubel di Home Industry Meubel di Kelurahan Antang Kecamtan Manggala ini diberikan setelah pengantaran dan pemasangan selesai. Rata-rata para 
pemilik meubel memberikan upah kekaryawannya secara penuh setelah pengantaran. Para pemilik meubel jarang memberikan uang muka untuk para karyawanya dengan alasan setelah di berikan uang muka, para pekerja akan malas bekerja dan akan berdampak pada waktu penyelesaian.

Karyawan diberikan upahnya setelah pekerjaan selesai dikarenakan sistem pengupahan di Home Industry Meubel di Kelurahan Antang Kecamtan Manggala hampir semua menggunakan sistem pengupahan borongan. Dalam pengertianya sistem upah borongan, pekerja yang bekerja pada pengusaha untuk melakukan pekerjaan tertentu dengan menerima upah didasarkan atas volume pekerjaan atau satuan hasil kerja.

pemilik usaha meubel agan segera membayarkan upah kepada para karyawanya sesuai dengan perjanjian diawal yang diamana perhitungnanya didasari dengan bahan dasar meubel dan kemudian akan diukur, seelah diukur maka ukuran permeter dari bahan tersebut yang menjadi dasar penentuan upah karyawan meubel pada home industry meubel di Kelurahan Antang Kecamtan Manggala.

Pada home industri meubel ini pekerja yang dipekrjakan bukanlah pekerja tetap, melainkan pekerja kontrak. Dimana para kerja ini di panggil pada saat pesanan ada dan akan bertambah jika pesanan banyak.

Selanjutnya untuk perbedaan upah karyawan yang memiliki prestasi kerja tidak di terapkan di kedua usaha meubel ini, hal ini dikarenakan sistem upah yang digunkan menggunakan sistem upah borongan, yang dimana sistem ini dikerjakan sesuai perjanjian waktu dan upahnya pun telah dibicarakan sebelumya.

\section{Perspektif Islam atas Sistem Pengupahan di Industri Mebel Rumahan Antang}

Dari hasil penelitian yang dilakukan, untuk menetapkan upah yang sesuai dengan kaidah Ilmu Ekonomi Islam maka harus memenuhi beberapa karakteristik diantaranya:

1. Upah Harus Disebutkan Sebelum Pekerjaan Dimulai

Pada Home Industry Meubel di Kelurahan Antang Kecamtan Manggala, sebelum para karyawan mengerjakan pesanan konsumen, terlebih dahulu dilakukan perjanjian kerja atara pemilik usaha dan pekerja. Disana penetapan upah di tentukan di awal, di sini terjadi pembicaraan antara pemilik usaha dan pekerja.

Perjanjian kerja ataua upah disebutkan sebelum pekerjaan di mulai; Rasulullah SAW memberikan contoh yang harus dijalankan kaum muslimin setelahnya, yakni penentuan upah para pekerja sebelum mereka mulai menjalankan pekerjaannya. 66 Rasulullah SAW bersabda; yang artinya : 
Dari Abi Said al Khudri ra. sesungguhnya Nabi SAW bersabda: "Barang siapa mempekerjakan seorang pekerja, maka harus disebutkan upahnya” (H.R. Abdur Razak sanadnya terputus, dan al Baihaqi menyambungkan sanadnya dari arah Abi Hanifah) kitab Bulughul Maram dan Ibanatul Ahkam.

Hadits tersebut Rasulullah telah memberikan petunjuk, supaya majikan terlebih dahulu memberikan informasi tentang besarnya upah yang akan diterima oleh pekerja sebelum ia mulai melakukan pekerjaannya. Dengan adanya informasi besaran upah yang diterima, diharapkan dapat memberikan dorongan semangat untuk bekerja serta memberikan kenyamanan dalam pekerjaan. Mereka akan menjalankan pekerjaan sesuai dengan kesepakatan kontrak kerja dengan majikan.

Para pengusaha home industri meubel pada home idustri meubel di Kecamatan Manggala, Kelurahan Antang ini pada umumnya telah menerapkan sistem pengupahan menurt perspektif ekonomi Islam yang dimana adanya kejelasan upah terlebih dahulu dalam bentuk perjanjian kerja dan kemudian para pekerja melakukan pekerjaanya.

\section{Membayar upah sebelum keringatnya kering}

Membayar upah sebelum keringatnya kering Rasulullah SAW menganjurkan majikan untuk membayarkan upah para pekerja setelah mereka selesai melakukan pekerjaannya. Ketentuan tersebut untuk menghilangkan keraguan pekerja atau kekhawatirannya bahwa upah mereka akan dibayarkan, atau akan mengalami keterlambatan tanpa adanya alasan yang dibenarkan. Namun, umat Islam diberikan kebebasan untuk menentukan waktu pembayaran upah sesuai dengan kesepakatan antara pekerja dengan yang memperkerjakan.

Demikian pula pada home industry meubel di Kelurahan Antang Kecamtan Manggala, upah karyawan akan segera di bayarkan saat setelah pemiluk usaha menerima biaya pembuatan meubel dari konsumen.

Sistem pengupahan pada home industri meubel di Kelurahan Antang Kecamatan Manggala telah mengikuti sistem pengupahan sesuai dengan perspektif ekonomi Islam. Dimana para pemilik usaha meubel akan membayarkan upah para karyawanya sesaat setelah para pemilik menerima biaya pembuatan meubel dari konsumen saat pesana konsumen tersebut di antarkan ke tempat tujuanya. Hal ini menghilangkan keraguan pekerja atau kekhawatirannya bahwa upah mereka akan dibayarkan, atau akan mengalami keterlambatan tanpa adanya alasan yang dibenarkan. Hal ini menunjukkan bahwa jika mempekerjakan seorang pekerja hendaklah dijelaskan terlebih dahulu upah yang akan diterimanya dan membayarkan upahnya sebelum keringat pekerja kering. Sehingga kedua belah pihak samasama mengerti atau tidak merasa akan dirugikan. 
Umat Islam diberikan kebebasan untuk menentukan waktu pembayaran upah sesuai dengan kesepakatan antara pekerja dan yang mempekerjakan. Demikian juga upah yang dibayarkan kepada para pekerja boleh dibayarkan berupa uang, barang, atau binatang ternak. Sebagaimana satu riwayat bahwa Umar bi Khattab pernah memberikan upah kepada gubernur Himsha yaitu Iyad bin Ghanam "berupa uang satu dinar,satu ekor domba, dan 1 mud kurma setiap hari.

Selain menerima upah para pekerja akan menerima bonus dari pemilik usaha meubel, bonus itu berupa saat setelah pengantara para pekerja yang telah mnyelesaikan pesanan dan mengantarkan pesanan meubel ke lokasi konsumen akan di ajak makan oleh pemilik usaha meubel. Adanya bonus seperti ini akan menambah semangat kerja para karywan dan akan menjalin hubungan kerja antara karyawan dan pemilik usaha meubel. Hal ini sejalan dengan teori di bab sebelumnya tentang hak pokok pekerja selain menerima upah hak pokok pekerja adalah pekerja harus diperlakukan dengan baik dan sopan dan dimaafkan jika mereka melakukan kesalahan dalam bekerja. Pekerja berhak menerima upah yang memungkinkan baginya menikmati kehidupan yang layak, hal ini merupakan salah satu hak pekerja, dan para pekerja pada home industri meubel di Kelurahan Antang, Kecamatan Manggala telah menikati hasil kerjanya dan mendapatkan kehidupan yang cukup untuk memenuhi kehidupanya sehari-hari.

Salah satu nilai yang di junjung tinggi dalam perspektif ekonomi islam ialah nilai keadilan dan kelayakan, dimana tidak adanya rasa keduah belah pihak dizalimi satu sama lain. Hal ini berarti bahwa pemilik dan pekerja sudah merasa adil, dimana pemilik mendapatkan keuntungannya dam pekerja mendapatkan gaji sesuai tenaga yang dikeluarkan, hal ini secara tidak langsung pada home industri meubel di Kelurahan Antang telah menerapkan sistem ekonomi perspektif Islam dimana nilai keidalan dan kelayakan antara pemilik dan pekerja telah terpenuhi.

\section{KESIMPULAN}

Berdasarkan hasil pembahasan pada terdapat 2 hal yang dapat dijadikan sebagai kesimpulan yaitu :

1. Sistem pengupahan pada home industri meubel di Kelurahan Antang Kecamtan Manggala menggunakan sistem pengupahan borongan, dimana sistem ini dipakai karena para pengusaha meubel ini mengejar target waktu penyelesain yang telah di janjikan kepada konsumen. Karyawan sebagai pembuat meubel yang diupah oleh pemilik usaha dari hasil pembuatan meubel, dituntut agar menyelesaikan meubel sesuai dengan tenggang waktu yang telah dijanjikan kepada konsumen. 
2. Sistem pengupahan pada home industri meubel persfektif ekonomi Islam di Kelurahan Antang Kecamtan Manggala ini secara tidak langsung telah menerapkan sistem pengupahan menurut Islam. Yang pertama ialah upah disebutkan sebelum pekerjaan di mulai, pada home industri meubel di Kelurahan Antang Kecamtan Manggala meneyebutnya dengan perjanjian kerja, sebelum pekerja membuat meubel perjajian kerja di lakukan dengan pemilik usaha meliputi : model yang akan di buat, bahan yang akan di pakai, panjang bahan yang di pakai, warna, waktu pengerjaan, dan yang terakhir ialah upah. Yang kedua adalah upah di bayar sebelum keringatnya kering, pada home industri meubel ini akan menerima upahnya setelah mereka melakukan pengantar dan pemilik usaha menerima biaya pembuatan dari konsumenya bahkan sebelum menerima upah, para pekerja di berikan bonus berupa makan gratis dari pemilik usaha atau upah yang lebih bila ada keuntungan yang didapatkan pemilik usaha meubel.

\section{DAFTAR PUSTAKA}

Albar, Muhammad. 2013. Aplikasi Nilai-Nilai Tauhid Dalam Comprate Social Rensponsibility CSR Pada Muhammad Bank Muamalat Cabang Makassar. Skripsi, tidak dipublikasikan. Fakultas Ekonomi dan Bisnis Islam, UIN Alauddin Makassar.

Antonio, Syafi'i. 1999. Bank Syariah Wacana Ulama dan Cendekiawan. Jakarta: Tazkiyah Institut.

Anwar, Samsul. 2007. Hukum Perjanjian Syariah: Studi Tentang Teori Akad Dalam Fiqih Muamalat. Jakarta: Raja Grafindo Persada.

Aziz S , Moh. Saifullah. 2005. Fiqih Islam Lengkap. Surabaya: Terang Surabaya.

Badan Pusat Statistika. 2004. Indikator Ketenagakerjaan Mei 2004. Jakarta: BPS.

Bungin, Burhan. 2009. Penelitian Kualitatif. Jakarta: Kencana.

Departemen Pendidikan Nasional. 2008. Kamus Besar Bahasa Indonesia. Jakarta. PT. Gramedia Pustaka Utama: 2008.

Hakim, Lukman. 2012. Prinsip-Prinsip Ekonomi Islam. Jakarta: Erlangga.

Idri. 2015. Hadis Ekonomi: Ekonomi dalam Perspektif Hadis Nabi. Jakarta: Prenadamedia Group.

Lukman, Hakim. 2012. Prinsip-prinsip Ekonomi Islam. Surakarta: Erlangga.

M. Kandarisman. 2014. Manajemen Kompensasi. Jakarta : Rajawali Pers.

Martoyo, Susilo. 1987. Manajemen Sumber Daya Manusia. Yogyakarta: BPFE UGM.

Masyhur, Kahar. 1992. Bulughul Maram. Jakarta: PT Rineka Cipta.

Natsir, Moh. 2003. Metode Penelitian . Jakarta: Ghalia Indonesia 
Qorashi, Baqir Sharief. 2007. Buruh. Jakarta: Al-Huda

Rahman, Afzalur. 1995. Economic Doktrines of Islam. Terjemahan Soeroyo dan Nastangin. Doktrin Ekonomi Islam. Jilid I.Yogyakarta: PT Dana Bhakti Wakaf.

Ridwan, Murtadho. Standar Upah Pekerja Menurut Sistem Ekonomi Islam. Jurnal Equilibrium Vol. 1 No. 2 Tahun 2013.

Rozalinda. 2016. Fikih Ekonomi Syariah: Prinsip dan Implementasinya pada Sektor Keuangan Syariah. Jakarta: Rajawali Pers.

S. Nasution. 2003. Metode Research. Jakarta: Bumi Aksara.

Sharief Qorashi, Baqir. 2007. Keringat Buruh. Jakarta: Al-Huda.

Suhendi, H. Hendi. 2016. Fiqh Muamalah. Jakarta: Rajawali Pers.

Sukirno, Sadono. 2005. Mikro Ekonomi Pengantar Teori Edisi III. Jakarta: Raja Grafindo Persada.

Swastha, Basu. 2007. Pengantar Bisnis Modern Pengatar Ekonomi Perusahaan Modern. Yogyakarta: Liberty. 